\title{
Discordances in ER, PR, and HER2 between primary breast cancer and brain metastasis
}

\author{
Jaehag Jung ${ }^{1} \cdot$ Seung Hoon Lee ${ }^{2,4} \cdot$ Mira Park $^{3} \cdot$ Ji Hye Youn ${ }^{4} \cdot$ Sang Hoon Shin ${ }^{4} \cdot$ Ho Shin Gwak $^{4} \cdot$ Heon Yoo $^{4}$ (I)
}

Received: 9 August 2017 / Accepted: 13 December 2017 / Published online: 19 December 2017

(c) The Author(s) 2017. This article is an open access publication

\begin{abstract}
When distant metastases are discovered, it is important to determine receptor profiles of these lesions through histologic examination. However, brain metastasis sites are difficult to reach to be routinely biopsied. The purpose of this study was to determine expression profiles of estrogen receptor (ER), progesterone receptor (PR), and human epidermal growth factor receptor 2 (HER2) in breast cancer brain metastasis (BCBM) and the existence of discordance between primary breast cancer and brain metastasis. A total of 37 patients who underwent craniotomies for metastatic brain tumors arising from breast cancer at National Cancer Center (NCC) of Korea between 2002 and 2014 were retrospectively reviewed. Clinicopathologic data were collected from electronic medical records. Receptor profiles of primary breast cancer and brain metastasis in each patient were identified. Data of ER, PR, and HER2 expression in brain metastasis were available in electronic medical records for $21(56.8 \%)$ of 37 cases. Results of ER, PR, and HER2 expression were positive in 47.6, 42.9, and 38.1\% of patients with brain metastasis, respectively. Receptor conversion occurred in $11(52.4 \%)$ of 21 patients (for ER, 9.5\%; for PR, 38.1\%; for HER2, 23.8\%). Overall survival was longer in patients with concordant receptor expression patterns between primary breast cancer and brain lesion compared to that in patients with discordant patterns. However, such difference was not statistically significant (discordant vs. concordant median survival: 19.2 versus 31.1 months, $p=0.181$ ). Receptor conversion in BCBMs was observed in over $50 \%$ of Korean patients used in this study. HER 2 conversion was observed in $23.8 \%$ of patients in this study. Therefore, if resistance to anti-HER2 treatment is suspected in patients with BCBM, biopsy is needed to determine receptor profiles of brain lesion.
\end{abstract}

Keywords Breast cancer $\cdot$ Brain metastasis $\cdot$ Discordance $\cdot$ Receptor conversion

Jaehag Jung and Seung Hoon Lee contributed equally as a co-first authors.

Heon Yoo

heonyoo@ncc.re.kr

1 Department of Surgery, Eulji University Hospital, Daejeon, South Korea

2 Department of Neurosurgery, Eulji University Hospital, Daejeon, South Korea

3 Department of Preventive Medicine, Eulji University, Daejeon, South Korea

4 Neurooncology Clinic, National Cancer Center Hospital, Goyang, South Korea

\section{Introduction}

Breast cancer is the second most common cancer in Korean women after thyroid cancer [1]. Early detection of this disease with screening and good standardized treatment has improved the prognoses of afflicted patients. However, approximately one-third of patients will develop distant metastases to the liver, bones, lungs, and brain. They eventually succumb to the disease.

Brain metastasis is the fourth most common metastatic site for patients with breast cancer. Its incidence rate ranges from 10 to $16 \%$ [2]. The rate of patients with breast cancer brain metastasis (BCBM) appears to be increased due to effective treatment of systemic disease and improved survival following diagnosis of primary cancer. In addition, improved imaging modalities have enabled early detection of subclinical diseases. Brain metastasis in patients with breast cancer has poor prognosis, with a median survival of 
2-9 months despite treatment [3, 4]. Current standard treatment options for brain metastases include local treatments such as surgery, stereotactic radiosurgery, and whole-brain radiotherapy (WBRT). Chemotherapy and targeted therapy have been reported to be effective for approximately 30-40\% of patients $[5,6]$. Expressions of hormone receptors (HRs) and human epidermal growth factor receptor 2 (HER2) are critical for determining personalized treatment options for patients with breast cancer. However, BCBMs are generally treated with chemotherapy on the basis of the receptor profile of primary breast cancer BCBMs are generally treated with chemotherapy on the basis of the receptor profile of primary breast cancer due to limited access to metastatic brain lesions which leads to the inability to determine their receptor expression profiles.

Previous studies have reported that receptor statuses of breast cancer metastases might differ from those of primary tumors [4, 7-13]. These studies have suggested that estrogen receptor (ER) and progesterone receptor (PR) are frequently negative in distant metastases whereas HER2 is often positive. However, the majority of these studies have focused on the correlation between lymph node metastasis and primary cancer. Few studies have compared immunophenotypes of breast cancer to those of brain metastases in Korean patients.

Therefore, the objective of this study was to determine expression patterns of ER, PR, and HER2 in Korean patients with breast cancer who underwent craniotomy due to brain metastases. Expression patterns of ER, PR, and HER2 were also compared between primary breast cancer tissues and brain metastases.

\section{Methods}

Records of consecutive patients who underwent craniotomy for metastatic brain tumors arising from breast cancer at the Neuro-oncology Clinic of the National Cancer Center of Korea between 2002 and 2014 were retrospectively reviewed. Thirty-seven consecutive patients who underwent craniotomy for BCBM were identified. Clinicopathologic data were collected from electronic medical records, including patient demographics, histological type, grade, tumor stage, biomarker status, date of diagnosis of breast cancer, subsequent brain metastases and craniotomy, number and locations of brain lesions, and survival. Patients with available data for ER, PR, and HER2 status were included in this study.

Status of ER and PR was determined by immunohistochemistry (IHC) reactivity. Samples with $1 \%$ or greater reactivity were defined as positive for both ER and PR receptors. HER 2 overexpression was defined as a membrane staining score of $3+($ HER $2+)$. Those with a score of $1+$ and 0 were defined as HER2-negative (HER2-). Fluorescent in situ hybridization was performed when HER2 IHC scores were equivocal $(2+)$.

The frequency of receptor expression in primary breast cancers and brain metastases was calculated. Overall survival, median survival, and 95\% confidence intervals (CIs) were estimated with Kaplan-Meier analysis. Brain metastasis-free survival was also estimated. Subgroups were compared using both overall and pairwise log-rank tests. Statistical analysis was performed using SPSS version 20.0 (IBM-SPSS, Armonk, NY, USA). A $p$ value of $<0.05$ was considered statistically significant. This study was approved by the Institutional Review Board (IRB) of the National Cancer Center, Korea.

\section{Results}

A total of 37 patients were included in this study. Their median age at initial diagnosis of breast cancer was 53.9 years (range 38-81). Patients' characteristics are summarized in Table 1. The histologic type of most patients was invasive ductal carcinoma (81.1\%, Table 1). Regarding TNM stage, those with stage II had the highest percentage (35.1\%, Table 1). Regarding histologic grade, those with grade 3 had the highest percentage (54.1\%, Table 1). Expressions of ER, PR, and HER2 in primary breast cancer were positive in $43.2,35.1$ and $51.4 \%$ of patients, respectively. Distributions of different biological subtypes of breast cancer were as follows: HR+/HER2- ,35.1\%; HR+/HER2+, 8.1\%; HR-/HER2+, 43.2\%; and HR-/HER2-, 13.5\%. Twentyeight $(75.7 \%)$ patients had solitary brain lesion at BCBM diagnosis (Table 1).

Results of brain metastasis-free interval, overall survival after breast cancer diagnosis, and overall survival after brain metastasis according to breast cancer subtypes are shown in Fig. 1. Brain metastasis free interval and overall survival after breast cancer were statistically different between groups. However, overall survival after brain metastasis did not differ significantly between groups.

Among 37 patients, data for ER, PR, and HER2 expression in brain metastasis were available for 21 cases based on electronic medical records. Expressions of ER, PR, and HER2 in brain metastasis were positive in 47.6, 42.9 and $38.1 \%$ of patients, respectively. Receptor conversion occurred in 11 of 21 patients (52.4\%): for ER, 9.5\%; for PR, 38.1\%; for HER2, $23.8 \%$ (Table 2). Overall survival was longer in patients with concordant receptor expression patterns between the primary breast cancer and brain lesion compared to that in patients with discordant patterns (Fig. 2). However, the difference was not statistically significant (discordant vs. concordant median survival: 19.2 vs. 31.1 months, $p=0.181)$. There was no statistically 
Table 1 Characteristics of patients included in this study

\begin{tabular}{|c|c|c|c|}
\hline Feature & Grouping & $\mathrm{N}$ or value & $\%$ \\
\hline \multirow[t]{2}{*}{ Age } & Mean & 53.9 & \\
\hline & Range & $38-81$ & \\
\hline \multirow[t]{3}{*}{ Histologic type } & Invasive ductal carcinoma & 30 & 81.1 \\
\hline & Others & 4 & 10.8 \\
\hline & Unknown & 3 & 8.1 \\
\hline \multirow[t]{4}{*}{ Histologic grade } & 1 & 1 & 2.7 \\
\hline & 2 & 8 & 21.6 \\
\hline & 3 & 20 & 54.1 \\
\hline & Unknown & 8 & 21.6 \\
\hline \multirow[t]{5}{*}{ TNM stage } & 1 & 6 & 16.2 \\
\hline & 2 & 13 & 35.1 \\
\hline & 3 & 9 & 24.3 \\
\hline & 4 & 1 & 2.7 \\
\hline & Unknown & 8 & 21.6 \\
\hline \multirow[t]{2}{*}{ ER status of primary tumor } & Positive & 16 & 43.2 \\
\hline & Negative & 21 & 56.8 \\
\hline \multirow[t]{2}{*}{ PR status of primary tumor } & Positive & 13 & 35.1 \\
\hline & Negative & 24 & 64.9 \\
\hline \multirow[t]{2}{*}{ HER2 status of primary tumor } & Positive & 19 & 51.4 \\
\hline & Negative & 18 & 48.6 \\
\hline \multirow[t]{4}{*}{ Primary breast cancer subtype } & HR+, HER2- & 13 & 35.1 \\
\hline & $\mathrm{HR}+, \mathrm{HER} 2+$ & 3 & 8.1 \\
\hline & HR-, HER2+ & 16 & 43.2 \\
\hline & HR-, HER2- & 5 & 13.5 \\
\hline \multirow[t]{2}{*}{ Multiplicity } & Single brain metastasis & 28 & 75.7 \\
\hline & Multiple metastasis & 9 & 24.3 \\
\hline \multirow[t]{3}{*}{ Brain metastasis location } & Supratentorial & 25 & 67.6 \\
\hline & Infratentorial & 8 & 21.6 \\
\hline & Both & 4 & 10.8 \\
\hline
\end{tabular}

$E R$ estrogen receptor, $P R$ progesterone receptor, $H E R 2$ human epidermal growth factor receptor $2, H R$ hormone receptor significant difference in median survival according to the conversion of each receptor (Table 3).

\section{Discussion}

Biomolecular markers are becoming the most important factors for systemic therapy of breast cancer patients such as hormonal therapy, chemotherapy, or targeted therapy. Studies performed in the last decade have revealed that receptor expression of metastatic lesions does not always reflect its status in primary tumor. To have more effective systemic therapy, molecular diagnosis through biopsy of metastatic lesions is strongly recommended. However, biopsies for brain metastases are not always performed in routine clinical practice due to limited access to metastatic brain lesions.

In terms of HER2, Niikura et al. [11]. have reported that the relatively frequent HER2 negative conversion rate is $24 \%$ in 182 patients with HER2-positive primary breast cancer and systemic metastasis. They have demonstrated that HER2 discordance is correlated with poorer survival. Therefore, they strongly recommend biopsies for metastatic lesions in primary HER2-positive breast cancer to obtain accurate molecular diagnosis and appropriate therapy. Lindstrom et al. [14] have also demonstrated that patients with HER2 discordant lesions have poorer survival. However, Amir et al. [15] have reported that HER2 discordance is not associated with detrimental effects on outcome.

There is no definite treatment guideline for BCBMs. The main goal is to alleviate symptoms when treating such tumors. If brain lesion is solitary or $<3$ lesions, it can be removed by craniotomy or radiosurgery. However, for cases of multiple brain metastases, WBRT and systemic therapy should be administered.

Recent studies have shown that anti-HER2 treatment can improve survival after BCBM diagnosis $[5,6,16]$. It 
Fig. 1 Brain metastasis free interval, overall survival after breast cancer diagnosis, and overall survival after brain metastasis according to breast cancer subtypes
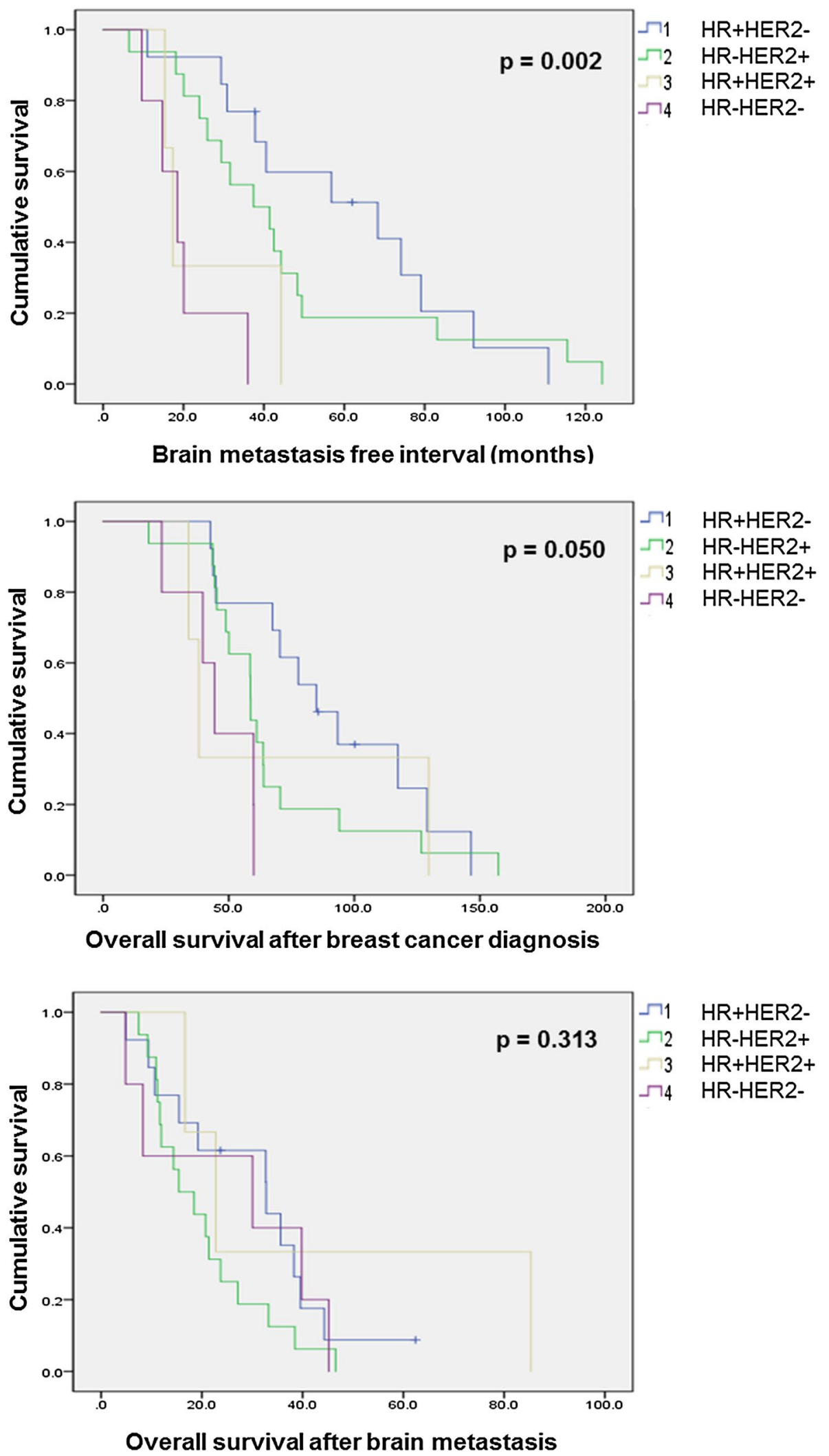
Table 2 ER, PR, and HER2 expression profiles in patients with primary breast cancer and brain metastasis

\begin{tabular}{lccr}
\hline $\begin{array}{l}\text { Brain metas- } \\
\text { tasis }\end{array}$ & \multicolumn{2}{l}{ Primary breast cancer } & \multicolumn{1}{l}{ Total } \\
\cline { 2 - 3 } ER status & - & + & \\
\hline- & $10(47.6 \%)$ & $1(4.8 \%)$ & $11(52.4 \%)$ \\
+ & $1(4.8 \%)$ & $9(42.9 \%)$ & $10(47.6 \%)$ \\
PR status & & & \\
- & $10(47.6 \%)$ & $2(9.5 \%)$ & $12(57.1 \%)$ \\
+ & $6(28.6 \%)$ & $3(14.3 \%)$ & $9(42.9 \%)$ \\
HER2 status & & & $13(61.9 \%)$ \\
- & $10(47.6 \%)$ & $3(14.3 \%)$ & $8(38.1 \%)$ \\
+ & $2(9.5 \%)$ & $6(28.6 \%)$ & \\
\hline
\end{tabular}

$E R$ estrogen receptor, $P R$ progesterone receptor, HER2 human epidermal growth factor receptor 2

is currently unclear whether such improvement is due to extracranial disease control or idirect intracranial tumor response. However, it has been reported that HER2-targeting agent trastuzumab can penetrate the impaired blood-brain barrier at the site of metastasis [17]. Swain et al. [18] have reported that adding pertuzumab to docetaxel and trastuzumab can delay the onset of brain metastases. Krop et al.
[19] have also reported that trastuzumab emtansine (T-DM1) is associated with significantly improved overall survival in patients with BCBM. Therefore, when response of antiHER2 treatment is poor in patients with BCBM, identifying receptor expression patterns in brain metastases should be considered.

Because it is difficult to reach brain metastasis sites, such sites are not routinely biopsied. A few studies have reported receptor status conversion between primary tumors and brain metastases [4, 7, 9, 10, 20-22]. However, most of these studies included small groups of BCBM. Thus, the incidence of receptor discordance between primary and metastatic tumor sites has not been conclusively established. Moreover, clinical impacts of receptor discordance such as prognosis and survivals in BCBM remain unclear.

Through the literature review, over 280 matched cases of BCBM were collected. Average discordance rates were 21.6\% (range 13.6-29.2\%) for ER, 26.7\% (range 4.2-44.4\%) for PR, and 10.7\% (range 2.3-19.0\%) for HER2 (Table 4). In a study by Duchnowska et al. [10], discordance rates for ER, PR, and HER2 status in primary tumor and brain metastases have been analyzed. In 120 cases of matched BCBM, discordance rates of ER, PR, and HER2 were 29, 24, and $14 \%$, respectively. However, receptor conversion showed no significant impact on survival.
Fig. 2 Overall survival comparison between the discordant and concordant groups

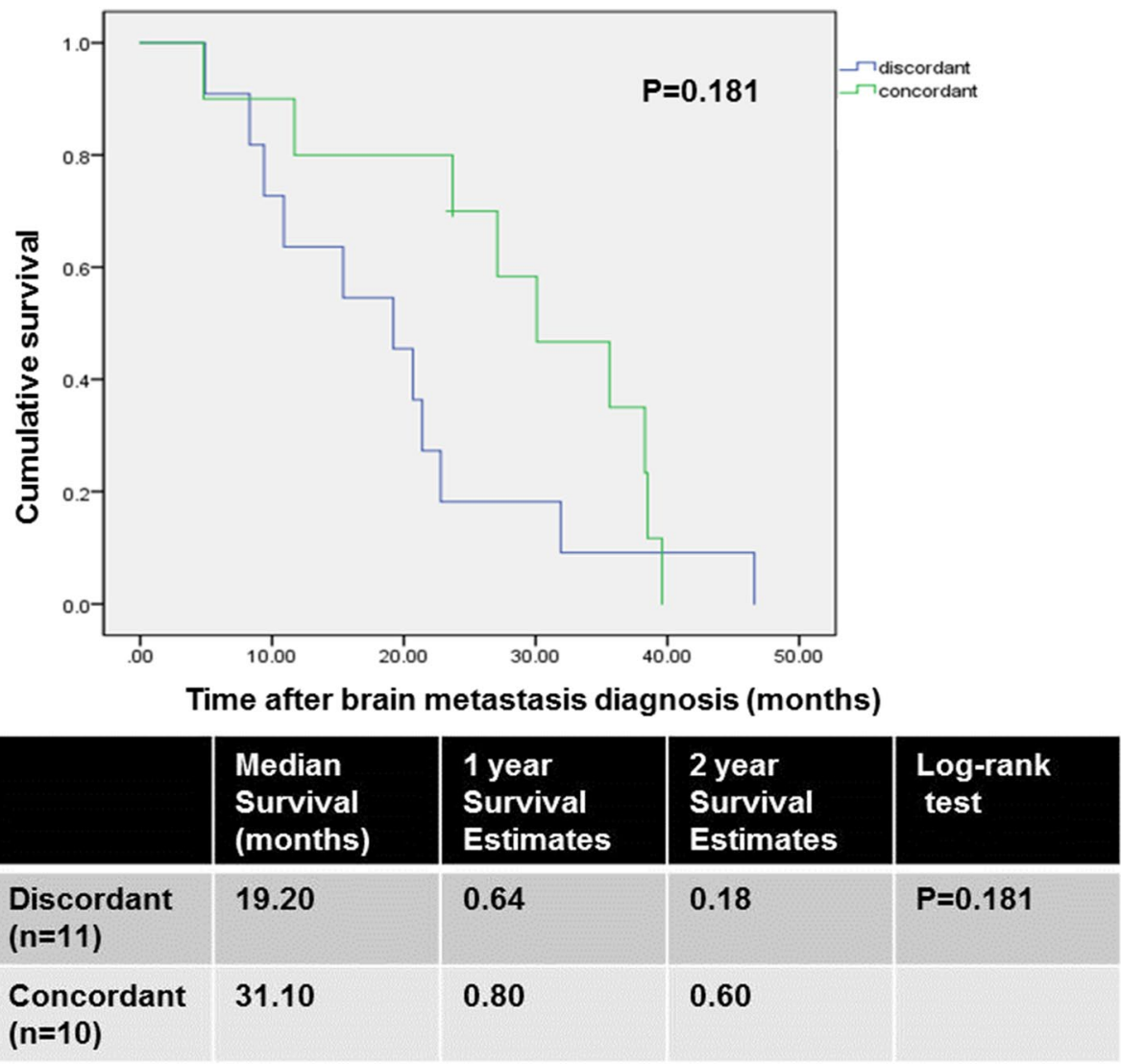


Table 3 Median survival comparison between the discordant and concordant groups according to receptor profiles in patients with primary breast cancer and brain metastasis

\begin{tabular}{lll}
\hline & $\begin{array}{l}\text { Median survival } \\
(\text { months })\end{array}$ & $\begin{array}{l}\text { Log-rank } \\
\text { test }(\mathrm{p} \\
\text { value })\end{array}$ \\
\hline $\begin{array}{l}\text { ER conversion } \\
\text { Discordant }(\mathrm{n}=2)\end{array}$ & 4.9 & 0.853 \\
Concordant $(\mathrm{n}=19)$ & 22.8 & \\
PR conversion & & 0.310 \\
Discordant $(\mathrm{n}=8)$ & 15.4 & \\
Concordant $(\mathrm{n}=13)$ & 30.1 & 0.389 \\
HER2 conversion & & \\
Discordant $(\mathrm{n}=5)$ & 21.4 & \\
Concordant $(\mathrm{n}=16)$ & 22.8 & \\
\hline
\end{tabular}

$E R$ estrogen receptor, $P R$ progesterone receptor, $H E R 2$ human epidermal growth factor receptor 2

In the present study, discordance rates of ER, PR, and HER2 status were 9.5, 38.1, and $23.8 \%$, respectively. About half of these cases showed discordance for more than one receptor. Our results showed less frequent ER changes but higher rate of discordance in HER2 than those of other studies. Reasons for such differences are currently unclear. However, it is known that breast cancer in Korean women has different epidemiological features compared to breast cancer in women from other countries [1]. First, the incidence of breast cancer is lower in Korea than that in western countries. Second, women in western countries are more likely to have breast cancer as their age increases. However, the incidence of breast cancer in Korean women increases until early $50 \mathrm{~s}$. It then gradually decreases thereafter. Third, the prevalence of breast cancer patients before menopause is much higher in Korea than that in western countries.

Any changes in receptor expression should be interpreted with caution as variation in processing of tissues can lead to incorrect results. Inadequate fixation can also result in false negatives or false positives. Although adequate fixation is achieved, receptor expression may be discordant due to intratumoral heterogeneity [23]. Changes in receptor expression might also occur due to tumor resistance to endocrine treatment [24] or HER2-targeted therapy [25].
Table 4 Systemic review of previous studies on receptor discordance between primary breast cancer and brain metastases

\begin{tabular}{|c|c|c|c|c|c|}
\hline & Markers & No. of cases & $\begin{array}{l}\text { Positive } \\
\text { conversion }\end{array}$ & $\begin{array}{l}\text { Negative } \\
\text { conversion }\end{array}$ & Total \\
\hline \multirow[t]{3}{*}{ Gaedcke et al. [16] } & ER & 23 & 2 & 4 & $6(26.1 \%)$ \\
\hline & PR & 23 & 2 & 3 & $5(21.7 \%)$ \\
\hline & HER2 & 23 & 2 & 1 & $1(4.2 \%)$ \\
\hline \multirow[t]{3}{*}{ Yonomori et al. [17] } & ER & 24 & 2 & 2 & $4(16.7 \%)$ \\
\hline & PR & 24 & 0 & 1 & $1(4.2 \%)$ \\
\hline & HER2 & 24 & 1 & 2 & $3(12.5 \%)$ \\
\hline \multirow[t]{3}{*}{ Omoto et al. [9] } & ER & 21 & 2 & 2 & $4(19.0 \%)$ \\
\hline & PR & 21 & 1 & 3 & $4(19.0 \%)$ \\
\hline & HER2 & 21 & 3 & 1 & $4(19.0 \%)$ \\
\hline \multirow[t]{3}{*}{ Hoefnage et al. [7] } & ER & 44 & NA & NA & $6(13.6 \%)$ \\
\hline & PR & 44 & NA & NA & $16(36.4 \%)$ \\
\hline & HER2 & 44 & NA & NA & $1(2.3 \%)$ \\
\hline \multirow[t]{3}{*}{ Shao et al. [18] } & ER & 18 & 0 & 1 & $6(16.2 \%)$ \\
\hline & PR & 18 & 4 & 4 & $8(44.4 \%)$ \\
\hline & HER2 & 18 & 1 & 0 & $1(5.6 \%)$ \\
\hline \multirow[t]{3}{*}{ Brogi et al. [4] } & ER & 37 & NA & NA & $6(16.2 \%)$ \\
\hline & PR & 39 & NA & NA & $8(20.5 \%)$ \\
\hline & HER2 & 40 & 0 & 2 & $2(5.0 \%)$ \\
\hline \multirow[t]{3}{*}{ Duchnowska et al. [10] } & ER & 120 & 13 & 22 & $35(29.2 \%)$ \\
\hline & PR & 119 & 11 & 18 & $29(24.4 \%)$ \\
\hline & HER2 & 119 & 10 & 7 & $17(14.3 \%)$ \\
\hline \multirow[t]{3}{*}{ Total } & ER & 287 & & & $62(21.6 \%)$ \\
\hline & PR & 288 & & & $71(26.7 \%)$ \\
\hline & HER2 & 289 & & & $31(10.7 \%)$ \\
\hline
\end{tabular}

$E R$ estrogen receptor, $P R$ progesterone receptor, HER2 human epidermal growth factor receptor $2, N A$ not applicable 
This study has some limitations. First, there might be methodological and selection biases due to the retrospective nature of this study. Biopsy and IHC analyses of primary and metastatic lesions were not performed simultaneously. Moreover, subjects of this study were patients who underwent craniotomy. Clinicians generally recommend surgery only for patients with favorable prognostic factors. Second, the total number of patients included in this study was small. Although treatment options for BCBM were local (such as surgery), breast cancer patients generally did not opt for brain surgery readily. However, the fact that this study was conducted at a single institution was an advantage in this regard since the overall treatment policies for patients and the anticancer drugs used were uniform. In addition, this study was meaningful because it was the first study that compared receptor profiles between primary breast cancer lesions and brain metastases in Korean population.

In conclusion, receptor conversion in BCBMs occurred in about $50 \%$ of Korean BCBM patients included in this study. HER 2 conversion was observed in $23.8 \%$ of these patients. Therefore, if the metastatic lesion is the brain alone, it is better to perform surgery than stereotactic radiosurgery because receptor profile of the distant metastatic site can be identified. Also, if resistance to anti-HER2 treatment is suspected in patients with BCBM, it should be considered the possibility that receptor conversion has occurred. Further studies are needed to determine whether differences in receptor expression levels between primary and metastatic brain lesions are prognostically relevant.

Acknowledgements This research was supported by the Ministry of Trade, Industry \& Energy (MOTIE), Korea Institute for Advancement of Technology (KIAT) through the Encouragement Program for The Industries of Economic Cooperation Region (R0003970, 2015).

\section{Compliance with ethical standards}

Conflict of interest The authors declare that they have no conflicts of interest.

Open Access This article is distributed under the terms of the Creative Commons Attribution 4.0 International License (http://creativecommons.org/licenses/by/4.0/), which permits unrestricted use, distribution, and reproduction in any medium, provided you give appropriate credit to the original author(s) and the source, provide a link to the Creative Commons license, and indicate if changes were made.

\section{References}

1. Oh CM, Won YJ, Jung KW, Kong HJ, Cho H, Lee JK, Lee DH, Lee KH (2016) Community of population-based regional cancer $\mathrm{R}$ : cancer statistics in Korea: incidence, mortality, survival, and prevalence in 2013. Cancer Res Treat 48(2):436-450
2. Lin NU, Bellon JR, Winer EP (2004) CNS metastases in breast cancer. J Clin Oncol 22(17):3608-3617

3. Lee SS, Ahn JH, Kim MK, Sym SJ, Gong G, Ahn SD, Kim SB, Kim WK (2008) Brain metastases in breast cancer: prognostic factors and management. Breast Cancer Res Treat 111(3):523-530

4. Brogi E, Murphy CG, Johnson ML, Conlin AK, Hsu M, Patil S, Akram M, Nehhozina T, Jhaveri KL, Hudis CA et al (2011) Breast carcinoma with brain metastases: clinical analysis and immunoprofile on tissue microarrays. Ann Oncol 22(12):2597-2603

5. Nam BH, Kim SY, Han HS, Kwon Y, Lee KS, Kim TH, Ro J (2008) Breast cancer subtypes and survival in patients with brain metastases. Breast Cancer Res 10(1):R20

6. Yap YS, Cornelio GH, Devi BC, Khorprasert C, Kim SB, Kim TY, Lee SC, Park YH, Sohn JH, Sutandyo N et al (2012) Brain metastases in Asian HER2-positive breast cancer patients: antiHER2 treatments and their impact on survival. Br J Cancer 107(7):1075-1082

7. Hoefnagel LD, van de Vijver MJ, van Slooten HJ, Wesseling P, Wesseling J, Westenend PJ, Bart J, Seldenrijk CA, Nagtegaal ID, Oudejans J et al (2010) Receptor conversion in distant breast cancer metastases. Breast Cancer Res 12(5):R75

8. Lin NU (2010) Concordance of HER2 in primary tumor and leptomeningeal metastases: now what? Breast Cancer Res Treat 123(1):129-131

9. Omoto Y, Kurosumi M, Hozumi Y, Oba H, Kawanowa K, Takei H, Yasuda Y (2010) Immunohistochemical assessment of primary breast tumors and metachronous brain metastases, with particular regard to differences in the expression of biological markers and prognosis. Exp Ther Med 1(4):561-567

10. Duchnowska R, Dziadziuszko R, Trojanowski T, Mandat T, Och W, Czartoryska-Arlukowicz B, Radecka B, Olszewski W, Szubstarski F, Kozlowski W et al (2012) Conversion of epidermal growth factor receptor 2 and hormone receptor expression in breast cancer metastases to the brain. Breast Cancer Res 14(4):R119

11. Niikura N, Liu J, Hayashi N, Mittendorf EA, Gong Y, Palla SL, Tokuda Y, Gonzalez-Angulo AM, Hortobagyi GN, Ueno NT (2012) Loss of human epidermal growth factor receptor 2 (HER2) expression in metastatic sites of HER2-overexpressing primary breast tumors. J Clin Oncol 30(6):593-599

12. Kroigard AB, Larsen MJ, Thomassen M, Kruse TA (2016) Molecular concordance between primary breast cancer and matched metastases. Breast J 22(4):420-430

13. Yeung C, Hilton J, Clemons M, Mazzarello S, Hutton B, Haggar F, Addison CL, Kuchuk I, Zhu X, Gelmon K et al (2016) Estrogen, progesterone, and HER2/neu receptor discordance between primary and metastatic breast tumours-a review. Cancer Metastasis Rev 35(3):427-437

14. Lindstrom LS, Karlsson E, Wilking UM, Johansson U, Hartman J, Lidbrink EK, Hatschek T, Skoog L, Bergh J (2012) Clinically used breast cancer markers such as estrogen receptor, progesterone receptor, and human epidermal growth factor receptor 2 are unstable throughout tumor progression. J Clin Oncol 30(21):2601-2608

15. Amir E, Miller N, Geddie W, Freedman O, Kassam F, Simmons C, Oldfield M, Dranitsaris G, Tomlinson G, Laupacis A et al (2012) Prospective study evaluating the impact of tissue confirmation of metastatic disease in patients with breast cancer. J Clin Oncol 30(6):587-592

16. Park IH, Ro J, Lee KS, Nam BH, Kwon Y, Shin KH (2009) Trastuzumab treatment beyond brain progression in HER2-positive metastatic breast cancer. Ann Oncol 20(1):56-62

17. Dijkers EC, Oude Munnink TH, Kosterink JG, Brouwers AH, Jager PL, de Jong JR, van Dongen GA, Schroder CP, Lub-de Hooge MN, de Vries EG (2010) Biodistribution of 89Zr-trastuzumab and PET imaging of HER2-positive lesions in patients with metastatic breast cancer. Clin Pharmacol Ther 87(5):586-592 
18. Swain SM, Baselga J, Miles D, Im YH, Quah C, Lee LF, Cortes J (2014) Incidence of central nervous system metastases in patients with HER2-positive metastatic breast cancer treated with pertuzumab, trastuzumab, and docetaxel: results from the randomized phase III study CLEOPATRA. Ann Oncol 25(6):1116-1121

19. Krop IE, Lin NU, Blackwell K, Guardino E, Huober J, Lu M, Miles D, Samant M, Welslau M, Dieras V (2015) Trastuzumab emtansine (T-DM1) versus lapatinib plus capecitabine in patients with HER2-positive metastatic breast cancer and central nervous system metastases: a retrospective, exploratory analysis in EMILIA. Ann Oncol 26(1):113-119

20. Gaedcke J, Traub F, Milde S, Wilkens L, Stan A, Ostertag H, Christgen M, von Wasielewski R, Kreipe HH (2007) Predominance of the basal type and HER-2/neu type in brain metastasis from breast cancer. Mod Pathol 20(8):864-870

21. Yonemori K, Tsuta K, Shimizu C, Hatanaka Y, Hashizume K, Ono M, Nakanishi Y, Hasegawa T, Miyakita Y, Narita Y et al (2008)
Immunohistochemical profiles of brain metastases from breast cancer. J Neuro-Oncol 90(2):223-228

22. Shao MM, Liu J, Vong JS, Niu Y, Germin B, Tang P, Chan AW, Lui PC, Law BK, Tan PH et al (2011) A subset of breast cancer predisposes to brain metastasis. Med Mol Morphol 44(1):15-20

23. Allott EH, Geradts J, Sun X, Cohen SM, Zirpoli GR, Khoury T, Bshara W, Chen M, Sherman ME, Palmer JR et al (2016) Intratumoral heterogeneity as a source of discordance in breast cancer biomarker classification. Breast Cancer Res 18(1):68

24. Nardone A, De Angelis C, Trivedi MV, Osborne CK, Schiff R (2015) The changing role of ER in endocrine resistance. Breast 24(Suppl 2):S60-S66

25. Pohlmann PR, Mayer IA, Mernaugh R (2009) Resistance to trastuzumab in breast cancer. Clin Cancer Res 15(24):7479-7491 